\title{
5 Structural Breaks and Governance Networks in Western Europe
}

Fabrizio Ferraro, Gerhard Schnyder, Eelke M. Heemskerk, Raffaele Corrado, and Nathalie Del Vecchio

Europe experienced a considerable "structural break" during the 1990s due to extensive liberalization policies, like those found in other regions around the globe. Indeed, European countries were involved in a unique project of harmonization and coordination of their policies within the framework of the European Union. In the late 1980s, pathbreaking European Directives paved the way for a common European market, first and foremost geared toward financial markets. The Single European Act, effective as of 1987, and the subsequent European Monetary Union led to a process of financial deregulation and to a wave of cross-border takeovers and acquisitions within the European market. These changes had multiple consequences for the functioning and organization of European economies, including non-EU members. However, there has been little exploration of their consequences for the national corporate governance regimes. In this chapter we analyze the impact of two structural breaks related to the liberalization and integration of European markets, privatizations, and governance reforms on a core aspect of corporate governance regimes: corporate networks.

Corporate networks are created, often unconsciously, by investors, board members, and managers through their business decisions, and become the social infrastructure of governance regimes. These networks affect many key corporate decisions, especially the ones related to the distribution of corporate control (mergers, acquisitions, etc.; see for a review Mizruchi, 1996). Through ties of (shared) ownership and interlocking directorates, corporations are tied together in a fabric of network relations. As such, these corporate networks are part of the institutional framework of national economies. Typically, the architecture of these networks reflects the national varieties of capitalism. Thus, German corporate networks are dense with banks occupying central positions, whereas countries such as Great Britain and the United States typically have much sparser corporate networks (Windolf, 2002; Windolf \& Beyer, 1996). Corporate networks can be expected to be affected by liberalization and market integration. Indeed, networks of interlocking directorates and capital ties may serve as a competition-regulating mechanism and have often been considered 
a sign of collusion (Mizruchi, 1996; Windolf \& Beyer, 1996). We would hence expect networks to be weakened by increasing liberalization that imposes potential structural breaks on the largely "coordinated market economies" (Hall \& Soskice, 2001).

Different studies indeed find signs of a certain "decomposition" of corporate networks in Europe in terms of their overall density and/or connectivity (for Switzerland and the Netherlands, see Heemskerk \& Schnyder, 2008; for Germany, Beyer \& Höpner, 2003, and Höpner \& Jackson, 2006; for France, Goyer, 2007). However, it has been argued that these changes in network structure do not necessarily affect their function (Gilson, 2000). Thus, Kogut and Walker (2001) have shown for the German case that despite considerable changes in network density, the network maintained its "small-world" characteristics, and could still play its role as institutional infrastructure for coordination, information exchange, and control.

Small-world (SW) networks facilitate fast information diffusion given their short average path length, and this property also operates in sparse networks. We argue, however, that small-world measures are not sufficient to explain the paths followed by corporate governance regimes. Indeed, small-world coefficients, like any structural approach, can help us understand how network structures constrain or facilitate actors' behavior. At the same time, by neglecting the identities and the behavior of these actors, small-world analysis of corporate networks may lead us to posit continuity in coordinated market economies - based on the continuity in the structural features of the network - while important changes actually took place.

In this chapter, we analyze the evolution of corporate networks in three countries belonging to the German variety of capitalism (Germany, the Netherlands, and Switzerland) and three belonging to the Latin type (France, Italy, and Spain) by comparing their ownership and interlock networks for two points in time, one in the early 1990s one in the early 2000s. We first show that, in terms of network topology, the countries follow multiple change trajectories but also experience some convergence. All the networks studied (1) can still be characterized as small world by the early 2000s, and (2) their small-world coefficients become more similar over the 1990s-meaning that the countries' corporate networks are topologically more similar after the liberalization breaks. This continuity and convergence does not necessarily translate into the reproduction of the same corporate governance form. Change may be hidden beneath the persistence in topological and functional characteristics of the network. If we understand corporate networks as a form of social institutions (Gilson, 2000), they constitute merely an opportunity structure creating resources and constraints for actors. Hence a central question becomes, which actors use these opportunity structures and to what ends?

At the same time, structural features do constrain actors' behavior and decisions, which in turn affect the network structure. Thus our study shows that analyzing the macro-micro-macro transition (Coleman, 1990) - that is, analyzing the macrostruc- 
ture, but also its effects on microbehavior and how this microbehavior affects, in turn, the macrostructure - is essential to understanding the evolution of corporate networks. In other words, reintroducing "agency" into the study of corporate networks seems essential in order to understand what social mechanisms are at play in the transformations that coordinated market economies have undergone in recent years.

The starting point for our analysis is that European market economies have become more "market based". As noted, Europe has widely borrowed market institutions from the Anglo-Saxon model of market-based capitalism (Rajan \& Zingales, 2003). This evolution is - as in many countries - mainly the result of the process of "globalization" by which barriers to trade and capital flows among countries were removed and the value chains of companies became increasingly internationalized (see chapter 1). This development has shaken the traditional institutional arrangements on which the Western European coordinated market economies were built.

Different signs of this increasing Anglo-Saxonization of formerly coordinated market economies can be mentioned. Thus, the increasing Anglo-Saxonization goes together with a changing role of financial markets in the productive system. Table 5.1 reports some basic statistics on the evolution in the role of financial markets in the countries we will study (Germany, France, Italy, Spain, the Netherlands, and Switzerland). Even by a simple standard, such as the ratio of stock capitalization over gross domestic product, it is apparent that financial markets did play a more critical role in all of these countries by the end of the 1990s. This process should lead, many commentators have argued, to the diffusion of the Anglo-Saxon model of capitalism, and the demise of the traditional Germanic and Latin models.

When Europe's leaders met at Maastricht in 1991, the last thing they intended was for the monetary union to be a vehicle for spreading Anglo-Saxon capitalism. But that has been the most dramatic effect of the single currency. There were to be more equities and corporate bonds. And as these sources of financing grew, the capital markets were to exert their influence on all other sectors of the European economy, increasing the pressure on firms to perform. Pursuit of shareholder value, hostile takeovers, and better corporate governance-all of these elements were to become increasingly prominent features of the European landscape (Financial Times, 1998). Even authors writing from the "varieties-of-capitalism" perspective, who were very critical of the prospects for "convergence," admit that the changes in the financial markets have been so profound that they might disrupt national systems as a whole. In their influential book, Hall and Soskice (2001, p. 64) concede that "financial deregulation could be the string that unravels coordinated market economies."

Beyond financial deregulation and the implications it has had for financial companies, other "structural breaks" have had important consequences for the 
Table 5.1

The evolution of financial markets in Europe

\begin{tabular}{|c|c|c|c|c|c|c|}
\hline & France & Germany & Italy & Spain & Netherlands & Switzerland \\
\hline \multicolumn{7}{|c|}{$\begin{array}{l}\text { Stock market capitalization / } \\
\text { GDP }(\%)\end{array}$} \\
\hline $1990 \mathrm{~s}$ & 31.8 & 21.8 & 18 & 41 & 50 & 69 \\
\hline $2000 \mathrm{~s}$ & 80.4 & 43.7 & 63.3 & 69 & 203 & $323^{*}$ \\
\hline \multicolumn{7}{|c|}{$\begin{array}{l}\text { Domestic credit to private } \\
\text { sector / GDP }(\%)\end{array}$} \\
\hline $1990 \mathrm{~s}$ & 96.09 & 89.66 & 56.47 & 79.58 & 79.75 & 167.91 \\
\hline $2000 \mathrm{~s}$ & N/A & 120.3 & 77.55 & 101.59 & 147.9 & 165.2 \\
\hline \multicolumn{7}{|c|}{$\begin{array}{l}\text { Domestic credit provided by } \\
\text { the banking sector / GDP } \\
(\%)\end{array}$} \\
\hline $1990 \mathrm{~s}$ & 104.35 & 103.37 & 89.44 & 106.18 & 103.18 & 179 \\
\hline $2000 \mathrm{~s}$ & N/A & 147.54 & 98.52 & 119.75 & 160.4 & 179.23 \\
\hline \multicolumn{7}{|c|}{$\begin{array}{l}\text { Number of listed firms / } \\
\text { population }\end{array}$} \\
\hline $1990 \mathrm{~s}$ & 11.83 & 8.3 & 4.28 & 10.96 & 17.39 & 49.61 \\
\hline $2000 \mathrm{~s}$ & 10.89 & 7.9 & 4.66 & 22.25 & 15.14 & $34.01 *$ \\
\hline \multicolumn{7}{|c|}{$\begin{array}{l}\text { Initial public offerings / } \\
\text { listed firms (\%) }\end{array}$} \\
\hline $1990 \mathrm{~s}$ & 3.21 & 2.94 & 4.92 & N/A & N/A & N/A \\
\hline $2000 s$ & 4.82 & 2.31 & 6.91 & N/A & N/A & N/A \\
\hline
\end{tabular}

Source: World Development Indicators; OECD Financial Market Trends; Rajan and Zingales (2003). Notes: $*=1999 ; \stackrel{\ddagger}{=}$ number of companies with listed shares divided by population in millions.

organization of economies. For instance, different waves of privatization have broken out in national economies around the world since the 1970s (see Brune, Garrett, and Kogut, 2004, as well as chapter 3 in this volume) and, since privatization is a change from state to private ownership, these breaks precipitated a reconfiguration of national networks.

Another "structural break" analyzed in this chapter concerns the extensive changes in corporate laws around the world (see Lele \& Siems, 2006). Such corporate governance reforms aiming at increasing the protection of minority shareholders are a clear sign of the Anglo-Saxonization of systems where external shareholders formerly played a negligible role. Such reforms too may-in various ways - change the structure of corporate networks. Obviously other breaks, such as M\&As, might reconfigure national corporate networks but, given the scope of this chapter, we will focus only on privatization and corporate governance reform.

We argue that despite a certain "convergence" in network structures, the implications of these changes for the functioning of the economy largely depend on agency. In other words, as stated in chapter 1, corporate networks are first and foremost opportunity structures for social action. The impact of structural breaks on a national 
production system depends very much on which actors use these opportunity structures and how they use them. Similar changes in network structures may indeed lead to very different outcomes across countries.

\section{European Corporate Networks}

European corporate networks have been studied primarily as national systems and very few studies have explored these networks in a comparative manner. ${ }^{1}$ At least two distinct types of networks have been studied in this line of research: board interlock networks and ownership networks. In the first case, scholars collect data on the composition of boards of directors and explore the structure woven by directors sitting on more than one board. These directors create informal ties between firms that can become a conduit for information and influence. Ownership relationships have also been studied as a network. Scholars have explored, for instance, the corporate network created by common ownership (Kogut \& Walker, 2001), and the networks among owners (Corrado \& Zollo, 2006). In the first comparative study of interlocking directorships, Stokman, Ziegler, and Scott (1985) found large variation in the patterns of relationships among the largest corporations in each country, and in the role of financial institutions in particular. Windolf (2002, p. 224) compares Germany, France, Switzerland, and the Netherlands with the Anglo-Saxon model (UK and U.S.) and concludes that by the mid-1990s, "The institution of relational contracting within corporate networks has been weakened and is, to some extent, replaced by arm's length market transactions on the one hand, and direct state regulation on the other."

Our study expands on these previous contributions by focusing on the changes in networks from the early 1990 s to the early 2000 s.

\section{Methods}

We decided to compare countries that have often been associated with different varieties of capitalism in Europe: Germany, France, Italy, Spain, the Netherlands, and Switzerland. Rhodes and Van Apeldoorn (1998) identify three types of capitalism in Western Europe: Anglo-Saxon, Germanic (Germany, Austria, the Netherlands, and Switzerland), and Latin (France, Spain, and Italy). Our sample therefore covers the latter two types of capitalism according to this typology. Both Germanic and Latin capitalism are characterized by the primacy of coordinated action and regulation through network relations, but while the Germanic model stresses the role of banks and trade unions, Latin capitalism is characterized by a more statist approach. It has been argued that "neither model is likely to serve as a template at the European level, where regulation is strongly biased toward market-oriented 
negative integration" (Jackson \& Deeg, 2006, p. 28). The varieties of capitalism considered in this chapter, therefore, while not statistically representative of all European countries, include two of the most important European models (with the exception of the "pure" Anglo-Saxon variety and the Scandinavian model, analyzed respectively in chapters 2 and 6 ).

As a point of reference, the varieties-of-capitalism approach arrays countries between two poles of "coordinated market economies" and "liberal market economies"; see the discussion in chapter 1. Our approach takes another dimension into account to explain the variance that we observe in the continental European countries and that corresponds to a geographic division between northern and southern Europe, or Germanic and Latin cultures. We eschew the historical and cultural explanations for this division but instead focus on the activism of the state in the economy, in particular on the traditionally much higher degree of state ownership in the Latin economies. It is tempting to see this distinction as one of centralized and federal systems, which would surely fit a German and French comparison; however, this would not easily capture differences between, say, Spain and Italy on the one hand given their regionalized political systems, and Switzerland on the other, given the importance of its cantons. Rather, we propose that the legacy of strong proactive governments in Italy and Spain due to their fascist creation of state-owned industrial and financial entities (maintained in Italy even after the collapse of fascism) and the postwar nationalizations in France (renewed in the 1980s) created industrial structures and "habits of mind" that differ significantly from northern European counterparts.

Our question is how these economies responded to the structural breaks posed by privatization, the liberalization of capital markets, and the diffusion of liberal governance codes. We collected data on the boards of directors and ownership structure of a sample of corporations representative of the economy in terms of sectoral differentiation and size of the economy. We collected at least two separate panels for each country, one for the early 1990s and the other for the early 2000s (due to data availability we could not obtain data for the same years for all countries). We analyzed both interlock and ownership networks. In the ownership network, two firms are connected if they are both owned by the same owner (we used a $5 \%$ threshold of ownership in order to capture only ownership stakes that provide a level of influence in corporate affairs). All the data were cleaned and all the network statistics were computed following the guidelines described in appendix 1. In this chapter, we use the clustering definition of Watts and Strogatz (1998) to compute the small-world statistics, but utilizing the Robins-Alexander bipartite correction.

We first provide a descriptive analysis of the topological characteristics of these networks, and then use the small-world statistics to compare the relative position 
of the countries and their evolution during the 1990s. Small-world networks are characterized by short average path length (how many intermediaries are on the shortest path length between any two actors) and high clustering coefficient (how many of an actor's contacts are connected to each other) (Watts \& Strogatz, 1998). The advantage of the small-world concept is that it looks beyond the purely structural features of a network and asks what consequences a certain network structure has for its functional properties. Indeed, one of the main implications of small-world networks is that they may serve-despite the sparseness of ties between the nodesas an infrastructure for communication, coordination, and control (see chapter 1). Where clustering remains high and average path lengths short, information may flow quickly through the network even when the number of ties among nodes decreases. In other words, even dramatic decreases in network density may not necessarily affect the network's functional properties. The small-world measure hence constitutes a better measure of network change than other measures such as overall density or mean degree centrality. Furthermore, and this is critical in any comparative analysis, small-world coefficients can be meaningfully compared across networks of different scale.

\section{European Corporate Networks: Topological and Small-World Analysis}

Table 5.2 reports the number of nodes, number of ties, number of components, and percentage of nodes contained in the largest component (giant component) of the

Table 5.2

Board interlock networks in Europe: Nodes, edges, number of isolates, \% of nodes in the giant component and number of components (size $\geq 2$ )

\begin{tabular}{lllcllr}
\hline Country & Year & Nodes & Edges & $\begin{array}{l}\text { No. of } \\
\text { isolates }\end{array}$ & $\begin{array}{l}\text { \% nodes in G } \\
\text { component }\end{array}$ & $\begin{array}{l}\text { No. of } \\
\text { components }\end{array}$ \\
\hline IT & 1990 & 215 & 1088 & 12 & $91.63 \%$ & 4 \\
IT & 2000 & 198 & 1048 & 20 & $84.85 \%$ & 6 \\
ES & 1994 & 538 & 655 & 225 & $47.21 \%$ & 8 \\
ES & 2002 & 727 & 981 & 271 & $42.09 \%$ & 19 \\
FR & 1990 & 270 & 1041 & 48 & $81.48 \%$ & 2 \\
FR & 2000 & 435 & 1230 & 102 & $73.56 \%$ & 7 \\
DE & 1993 & 332 & 2275 & 28 & $89.76 \%$ & 4 \\
DE & 2000 & 546 & 3586 & 46 & $90.29 \%$ & 1 \\
CH & 1990 & 106 & 392 & 10 & $90.57 \%$ & 2 \\
CH & 2000 & 108 & 212 & 13 & $86.11 \%$ & 1 \\
NL & 1997 & 462 & 1142 & 123 & $68.62 \%$ & 4 \\
NL & 2001 & 443 & 719 & 184 & $51.92 \%$ & 4 \\
\hline
\end{tabular}

Note: In board interlock networks the nodes are corporations and the ties are the relationship created when one board member sits on the board of two (or more) corporations. 
interlock networks. Table 5.3 reports topological statistics on the giant component (number of nodes, number of ties, density, clustering coefficient, average path length) and the Small World Index (SWI). Consistent with previous research, we can observe that these networks are very sparse (the highest-density country being Switzerland with a score of 0.09 in 1990). Due to the low density characteristic of corporate networks, it has been argued that any kind of coordinated action is unlikely to emerge from these sparse networks, which could hardly be distinguished from random graphs (see chapter 1). The small-world analysis shows that considerable structure can exist despite low density; we will rely on the small-world indicators as evidence of local clustering and global connectedness that can support coordination and information.

Tables 5.4 and 5.5 report the same topological measures for the ownership network (i.e., the ties created by common ownership). In this case the density of the networks is generally higher, meaning that many corporations in the countries studied are connected through common ownership. Table 5.6 reports the SWI for all the countries studied in this chapter, and compares them across the two panels of data available (tables 5.3 and 5.5 report more detailed measures on the construction of the SWI). It is immediately clear that all of these networks can be characterized as small world, given that the SWI is larger than one. In the early 1990s, the comparison of the small-world coefficients for interlocks shows that Germany and France were characterized by relatively high SW indicators, followed by Italy, the Netherlands, Switzerland, and Spain.

During the 1990s, given the trend toward the more market-based forms of economic organization outlined earlier in the chapter, we expect the "small worldliness" of these corporate networks to decrease as the average path length of ties between companies increases and local clustering decreases. Indeed, the existence of interlocks is often criticized by advocates of shareholder-oriented models of corporate governance as a form of collusion (see, e.g., Daum \& Neff, 2004). Lower local clustering, coupled with approximately the same average path length, would indeed make these networks more similar to random graphs (see appendix 1). On the other hand, previous empirical research on Germany (Kogut \& Walker, 2001) and the United States (Davis and Yoo, 2003) would lead us to expect that corporate networks will be robust to environmental shocks. Change in the SW indicators should hence be limited. Our findings are not completely consistent with either perspective, because we find different directions of change in different countries.

Consistent with previous empirical studies, we find that all these countries had interlock networks that were still small worlds at the beginning of the new century. They displayed considerable cohesion and therefore provided the opportunity for coordination. However, two countries were distinct outliers-Germany and France- 


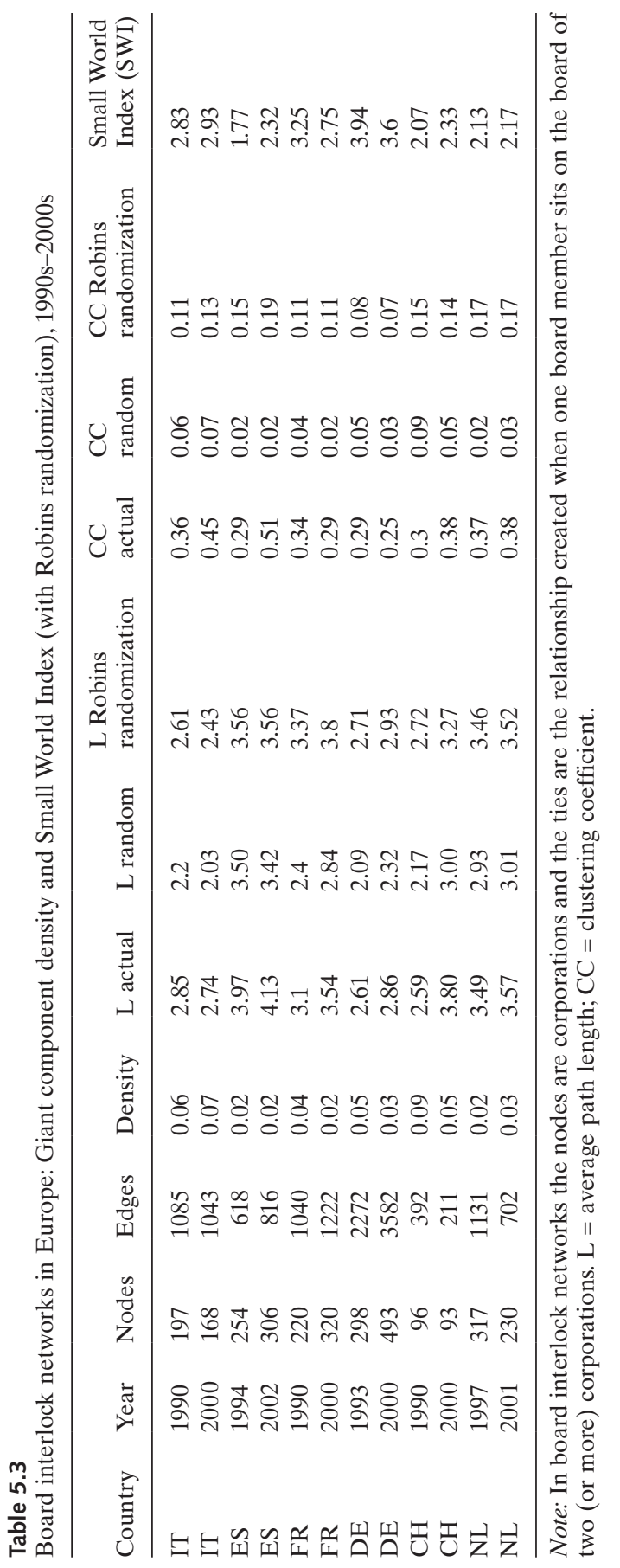


Table 5.4

Ownership networks in Europe: Nodes, edges, number of isolates, \% of nodes in the giant component and number of components (size $\geq 2$ )

\begin{tabular}{lcccccc}
\hline Country & Year & Nodes & Edge & $\begin{array}{l}\text { No. of } \\
\text { isolates }\end{array}$ & $\begin{array}{l}\text { \% nodes in giant } \\
\text { component }\end{array}$ & $\begin{array}{l}\text { No. of } \\
\text { components }\end{array}$ \\
\hline IT & 1990 & 212 & 314 & 92 & $22.17 \%$ & 13 \\
IT & 2000 & 207 & 112 & 126 & $8.70 \%$ & 22 \\
ES & 1994 & 452 & 730 & 253 & $19.25 \%$ & $10^{*}$ \\
ES & 2002 & 650 & 575 & 412 & $18.92 \%$ & 15 \\
FR & 1990 & 286 & 1175 & 113 & $44.76 \%$ & 19 \\
FR & 2000 & 509 & 1157 & 219 & $41.26 \%$ & 30 \\
DE & 1993 & 501 & 1351 & 174 & $47.90 \%$ & 31 \\
DE & 2000 & 457 & 1066 & 187 & $35.67 \%$ & 8 \\
CH & 1991 & 87 & 32 & 60 & $11.49 \%$ & 7 \\
CH & 2000 & 313 & 363 & 162 & $32.50 \%$ & 4 \\
NL & 1997 & 388 & 2365 & 183 & $38.92 \%$ & 4 \\
NL & 2001 & 149 & 622 & 76 & $40.27 \%$ & 4 \\
\hline
\end{tabular}

Note: In ownership networks the nodes are corporations and the edges are the relationship created when an owner (individuals, funds, or corporations) controls shares of two (or more) corporations. Only shareholdings above a $5 \%$ threshold were used to build these networks.

*Spain 1994: All state-owned companies are in a separate component with 34 nodes and 239 edges.

as we can see in table 5.6. In Germany, the SWI for board interlocks dropped by $15 \%$; in France it dropped by $9 \%$. All other countries showed increasing SWI. The cases of Spain and Switzerland are also interesting because their ownership network SW indicators increased in important ways, by approximately $30 \%$ and $13 \%$ respectively. The SW coefficients for Italy and the Netherlands increased, too, but only by $4 \%$ and $2 \%$ respectively.

Despite the diverging trends in different countries, by 2000, the board interlock networks of these six countries had become more similar in terms of their smallworld properties than they were in the early 1990s. The standard deviation of their SW indicators dropped from 0.7 to 0.3 , around an average indicator of 2.7. Summarizing, the board interlock networks were becoming more homogeneous in terms of their small-world network structure, but the direction of the change varies by country.

Table 5.7 reports the SW indicator of the ownership networks. In the early 1990s, France and the Netherlands were characterized by the highest small-world ratios, while Germany, Spain, and Italy followed, and Switzerland's ratio barely made it above one. ${ }^{2}$ At the beginning of the new century, as in the case of the interlock network, we observe some convergence among countries, driven primarily by the dynamics of Switzerland, the Netherlands, and Spain. Switzerland became much more clearly a small world (the SWI was 2.1 times what it was in 1990). Italy and Germany also increased their SWI in important ways, but not as much as 


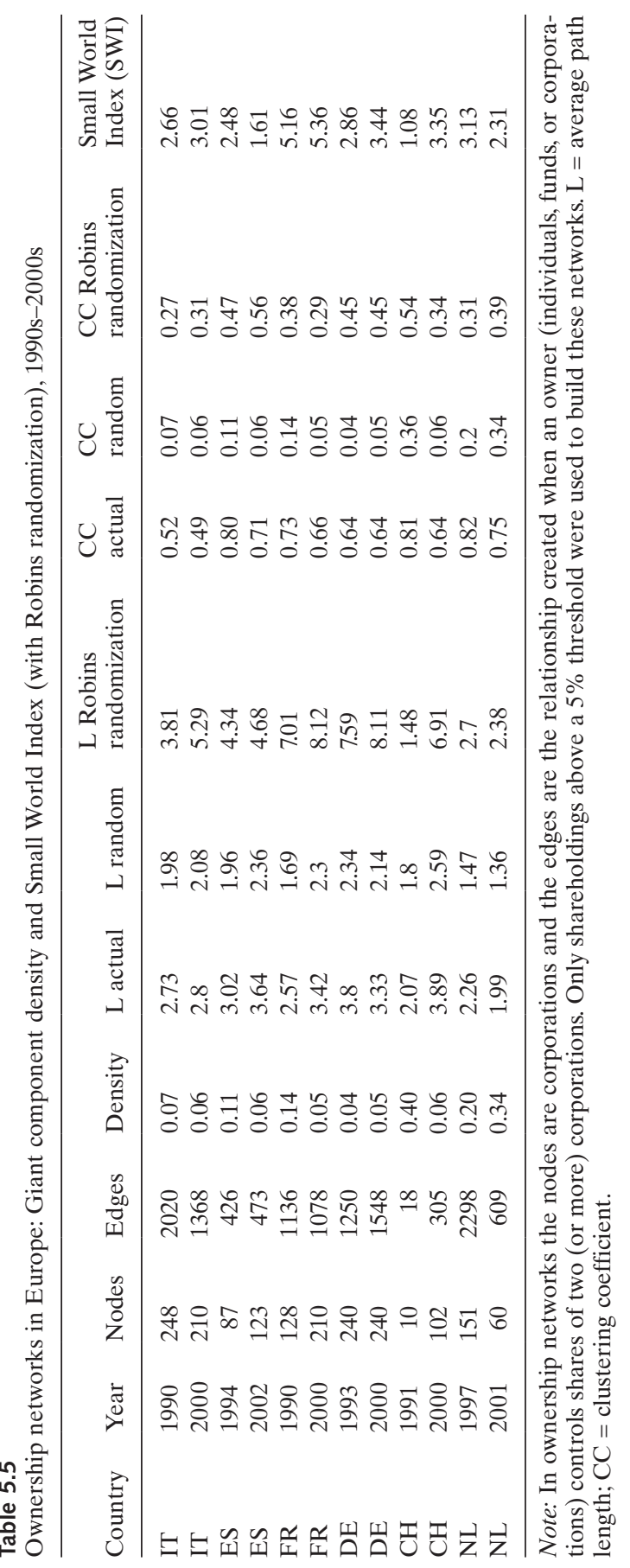


Table 5.6

Board interlock network Small World Index (Robins randomization), 1990s-2000s

\begin{tabular}{lllcc}
\hline Country & $\begin{array}{l}\text { Small World Index } \\
(\text { SWI }), 1990 s\end{array}$ & $\begin{array}{l}\text { Small World Index } \\
(\text { SWI }), 2000 s\end{array}$ & Change & Change \% \\
\hline IT & 2.83 & 2.93 & $4 \%$ & 0.1 \\
ES & 1.77 & 2.32 & $31 \%$ & 0.55 \\
FR & 3.25 & 2.75 & $-15 \%$ & -0.5 \\
DE & 3.94 & 3.6 & $-9 \%$ & -0.34 \\
CH & 2.07 & 2.33 & $13 \%$ & 0.26 \\
NL & 2.13 & 2.17 & $2 \%$ & 0.05 \\
Mean & 2.7 & 2.7 & & \\
Standard deviation & 0.7 & 0.3 & & \\
\hline
\end{tabular}

Table 5.7

Ownership network Small World Index (Robins randomization), 1990s-2000s

\begin{tabular}{lllrr}
\hline Country & $\begin{array}{l}\text { Small World Index } \\
(\text { SWI }), 1990 s\end{array}$ & $\begin{array}{l}\text { Small World Index } \\
(\text { SWI }), 2000 s\end{array}$ & Change & Change \% \\
\hline IT & 2.66 & 3.01 & 0.35 & 13 \\
ES & 2.48 & 1.61 & -0.87 & -35 \\
FR & 5.16 & 5.36 & 0.2 & 4 \\
DE & 2.86 & 3.44 & 0.58 & 20 \\
CH & 1.08 & 3.35 & 2.27 & 210 \\
NL & 3.13 & 2.31 & -0.82 & -26 \\
Mean & 2.9 & 3.2 & & \\
Standard deviation & 1.74 & 1.62 & & \\
\hline
\end{tabular}

Switzerland. France experienced only a moderate increase, while Spain and the Netherlands became less of a small world.

The interpretation of the trajectories emerging from the analysis of the smallworld ratio is far from unequivocal, but some conclusions can be drawn: in topological terms, European corporate networks do seem to be converging toward a similar small-world structure. These results become clearer in the visual representations provided in figures 5.1 and 5.2 (in addition to the countries we studied, we included the SWI for the United States as a benchmark). Table 5.8 summarizes this comparison. From these graphs another finding is apparent: most countries did not change much in terms of average path length, but did change in terms of local clustering. Indeed the countries moved on the vertical axis, while they did not move much on the horizontal one (with the exception of Switzerland). Again, while all six countries appear to have moved closer together concerning the small worldliness of their corporate networks, the trajectories that brought them there are varied. 


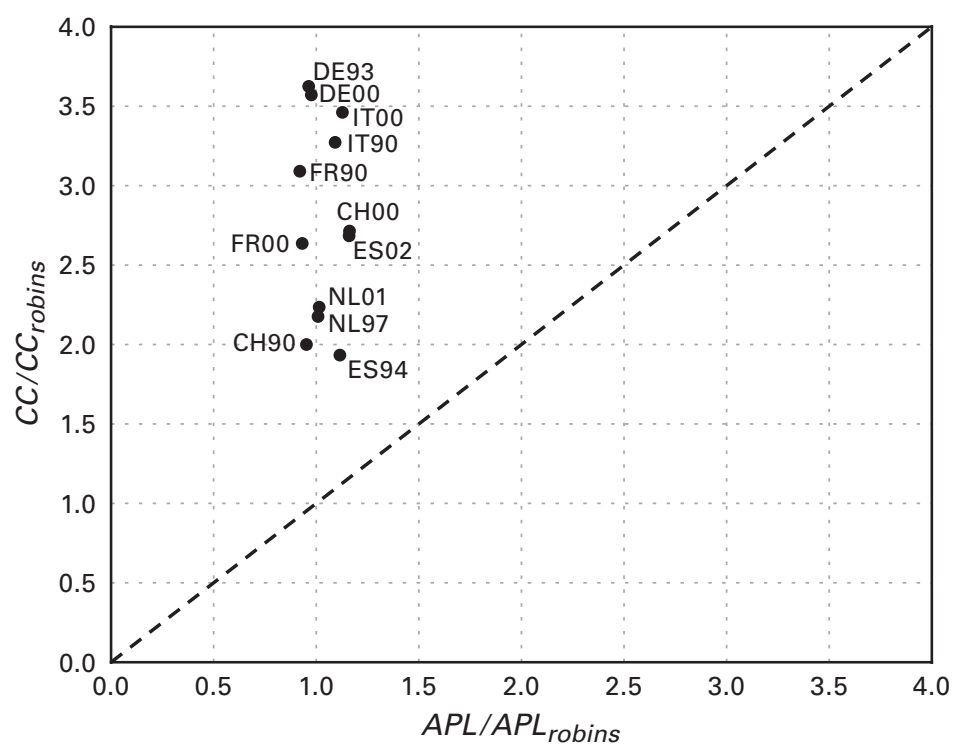

Figure 5.1

Small World Index (SWI) for board interlocking networks

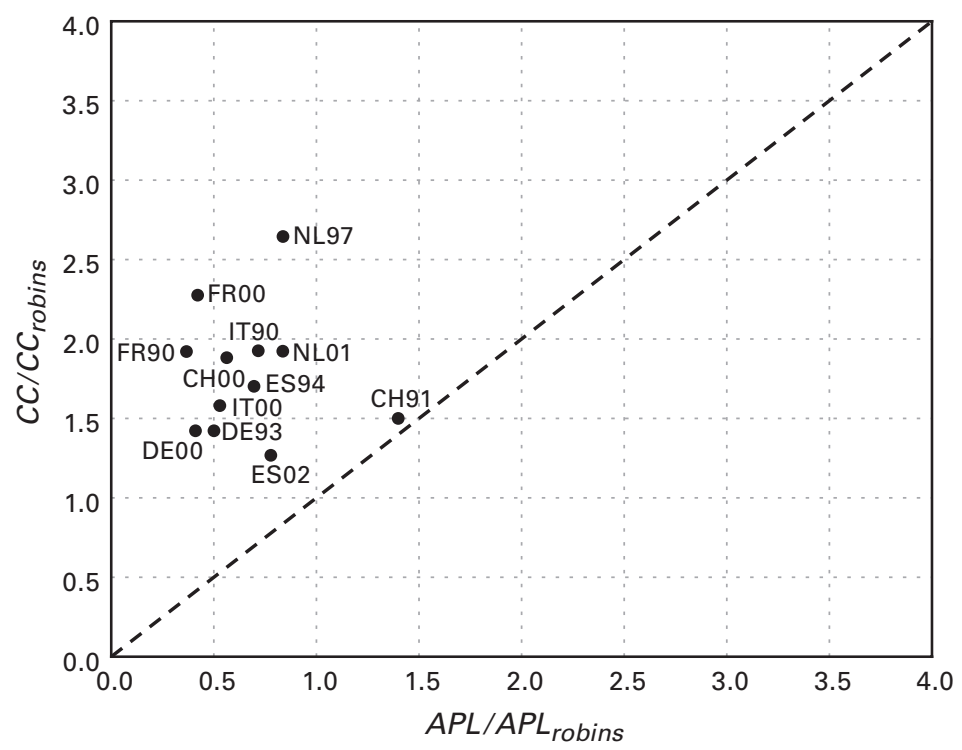

Figure 5.2

Small World Index (SWI) for ownership networks 
Table 5.8

Changes in small-world indicators in board interlock and ownership networks, 1990s-2000s

\begin{tabular}{llll}
\hline & & \multicolumn{2}{l}{$\Delta \mathrm{SW}$ interlock network } \\
\cline { 3 - 4 } & & + & - \\
\hline $\begin{array}{l}\text { S SW ownership } \\
\text { network }\end{array}$ & + & Italy, Switzerland & France, Germany \\
& - & Spain, Netherlands & - \\
\hline
\end{tabular}

Interestingly, we do not find any country in which the SWI of both types of corporate networks - board overlaps and ownership-unequivocally declined. Structure persisted in the 1990s despite many of the policy pressures discussed below. This persistence is in itself an interesting finding, which suggests that changes are more complex than an outright convergence to an Anglo-Saxon model. Two countries, Italy and Switzerland, experienced increases in the SWI for both networks. Two other countries, Spain and the Netherlands, experienced an increase in the SWI for the interlock network, but a very marked decrease in the ownership networks' small-world statistic. In France and Germany, finally, interlock networks were less connected (in terms of SWI) while ownership networks were now characterized by a higher SWI. These patterns do not suggest that ownership and director networks substitute for each other - that is, they might be functionally equivalent and thereby render the other redundant. On the contrary, these patterns suggest that small-world structures are present in both types of governance networks, though the strength of one or the other will vary by country.

The following sections explore different economic, institutional, and political factors in order to explain these varied trajectories. We focus in an exploratory fashion on two structural breaks that are usually associated with the recent wave of "globalization" and that have had important consequences for national production regimes around the world: privatizations and corporate governance reforms. The focus of the analysis lies in exploring how different actors use these structural breaks in different contexts, thus leading to different outcomes, despite a convergence in terms of network structure.

\section{Privatizations}

Between the early 1980s and 2000, the proceeds raised by governments worldwide with privatizations exceeded $\$ 1.3$ trillion, and represented around $7.6 \%$ of the world economy (Brune, Garret, \& Kogut, 2004). Table 5.9 provides the data on privatization for our selected European countries. Governments all over Europe justified their privatization programs by saying they would help them raise revenue for the state, promote economic efficiency, reduce government interference in the economy, 
Table 5.9

Privatization in Europe between 1977 and 2000

\begin{tabular}{lllllll}
\hline & $\begin{array}{l}\text { GDP 1990 } \\
\text { constant 1995 } \\
\text { Country \$M) }\end{array}$ & $\begin{array}{l}\text { Privatization } \\
1977-1990 \\
\text { (US \$M) }\end{array}$ & $\begin{array}{l}\text { \% of 1990 } \\
\text { GDP }\end{array}$ & $\begin{array}{l}\text { GDP 2000 } \\
\text { constant 1995 } \\
\text { (US \$M) }\end{array}$ & $\begin{array}{l}\text { Privatization } \\
1990-1999 \\
\text { (US \$M) }\end{array}$ & $\begin{array}{l}\text { \% of 2000 } \\
\text { GDP }\end{array}$ \\
\hline IT & $1,030,052$ & 3,273 & $0 \%$ & $1,204,868$ & 86,747 & $7 \%$ \\
ES & 546,527 & 2,962 & $1 \%$ & 702,395 & 45,754 & $7 \%$ \\
FR & $1,473,221$ & 21,209 & $1 \%$ & $1,755,614$ & 69,718 & $4 \%$ \\
DE & $2,270,256$ & 5,712 & $0 \%$ & $2,680,002$ & 57,783 & $2 \%$ \\
CH & 308,429 & N/A & $0 \%$ & 335,570 & 5,268 & $2 \%$ \\
NL & 373,783 & 2,542 & $1 \%$ & 492,956 & 12,373 & $3 \%$ \\
\hline
\end{tabular}

Source: Brune, Garrett, and Kogut (2004)

but also develop the national capital markets by promoting shareholding (Netter \& Megginson, 2001). Most empirical work on the impact of privatizations in Western Europe has so far focused on efficiency and welfare effects, while its impact on the national corporate governance regimes has received scant attention. Instead, the analysis of the impact of privatizations has focused on ownership type (e.g., families) and the adoption of formal governance codes (García \& Ansón, 2007). The structure of corporate networks, an important aspect of national governance structure, has so far received little attention in the literature on the impact of privatizations.

But why should we expect privatizations to affect the structure of corporate networks? In post-World War II Europe, government ownership of companies in some countries, notably Italy and Spain, had created dual economic systems with little cross-ownership between the privately owned companies and government-owned ones (for Italy, see Aganin \& Volpin, 2005; Amatori \& Brioschi, 1997; Barca \& Trento, 1997). The privatization wave of the 1990s reconfigured ownership networks by overcoming this duality, and the effects of these policies can be captured in the topology of the networks. We would expect that the size of the privatization program in relation to the economy would be a key contingency factor: important topological shifts follow privatization only in the countries that experienced large privatization programs, such as Italy and Spain. Table 5.9 reports some basic statistics on the two waves of privatization in Europe (1977-1990) and (1990-2000). The first wave was clearly stronger in France and Germany, but since this wave was prior to 1990 when we begin our analysis, we focus on the second wave.

The scope of privatization in the Latin countries of Italy and Spain during the 1990s was much wider than in the four other countries. The privatization process in Spain started in the mid-1980s, under a socialist government, but did not gain momentum until the 1990s, and was finally completed by the year 2001, under a government headed by the center-right Partido Popular. Overall, 131 firms were privatized between 1985 and 2003. The last big operation was in 2001 when Sepi 
sold $48.5 \%$ of Iberia, the country's flag carrier. Therefore, by 2000 , the privatization process was virtually over in Spain, and during the 1990s privatizations reduced the public share of capitalization from 16\% in 1992 to almost zero in 2000. In Spain, the privatization of Repsol, Telefónica, Enagás, Gas Natural, Endesa, and many other large companies helped deepen the network of cross-shareholding and board interlock at the core of the economy (Arocena, 2004). Note that all the companies just mentioned are among the top 10 firms in terms of eigenvector centrality in the interlock network (see table 5.11, discussed below). In Spain, according to Cabeza and Goméz (2007), privatization led to a dramatic reshuffling of ownership structure with "the State having been replaced as major blockholder by new shareholders, often in the guise of either banks or savings banks, who hold significant stakes in $75 \%$ of the privatized firms" (García \& Ansón, 2007, p. 510). This outcome stemmed from the political goal of keeping control of the major Spanish corporations in Spanish hands: to avoid hostile takeovers, the government invited the largest Spanish banks and savings banks to acquire controlling stakes in the privatized companies, reinforcing the protection offered by the golden share.

In Italy, the most important privatization wave with impacts on the network structure was probably the one in the banking sector. Indeed, tables 5.11 and 5.12, which compare firms' centrality scores in the 1990s and 2000s, show that almost all of the top 10 firms in term of centrality in Italy were commercial banks once controlled by the state and currently controlled by banking foundations created to acquire the controlling stakes in the financial institutions. Interestingly, the SWI for the ownership network in Italy increased during the 1990s, which could be interpreted as indicating a positive effect of privatization on network connectedness. In Spain, on the other hand, the ownership network became less connected and was characterized by a lower SWI.

The comparison between the cases of Spain and Italy suggests that privatizations did not determine the direction of the change, but provided an occasion for the reorganization of governance relations. These differences can only be understood if we look at the different political and corporate agendas driving the change toward more small worldly (Italy) or less small worldly (Spain) ownership networks. While we do find some convergence in network structures, their implications may still vary a great deal across countries because different actors may profit from the new opportunities in different countries.

France had experienced many privatizations even after the first "great wave" of the late 1980s. During the period 1990 to 1999, privatizations amounted to the equivalent of $4 \%$ of GDP (see table 5.9). Since the beginning of the privatization waves in France in the 1980s, the French government pursued a policy of creating "hard cores" (noyaux durs) of large shareholders who would guarantee that the freshly privatized companies would not fall into the wrong (read: foreign) hands 
(Culpepper, 2009; Schmidt, 1999). Indeed, the noyaux durs of friendly shareholders were created by the French government through the purposeful placing of large blocks of the privatized companies' shares with shareholders considered "friendly" to the incumbent management. The privatizations obviously constituted a crucial structural break in the traditionally heavily state-centered French model. It led to the emergence of cross-shareholdings among major French firms that had not previously existed and increased the companies' independence from state intervention (Schmidt, 1999). These new ties may largely explain why the small worldliness of the French ownership network increased between 1990 and 2000. Given the extent of privatizations, it is, however, somewhat surprising that the change was not stronger. It should also be noted that the noyaux durs have become much softer since the early 2000s, as major blockholders-such as the AXA insurance group-have started to divest their shareholdings (Culpepper, 2009). Also, the massive inflow of foreign capital in France since the mid-1990s in the form of foreign institutional investments (see, e.g., Goyer, 2007; O'Sullivan, 2007) may have contributed in important ways in rewiring the French network.

Let's turn now to the northern European countries, where state ownership had never been as important as in Latin countries. In Switzerland, privatizations were very limited in number, since the central government never was a major owner of industrial companies. The major state-owned infrastructure enterprises, which were formerly legal entities governed by public law, such as the Federal Railway (SBB) and the PTT, were transformed into stock corporations governed by private law, but were not or were only partially privatized. The PTT was split up into Die Post and Swisscom AG and the latter was partially privatized and went public in 1998. Other than this major privatization, very little state ownership existed and changes in the ownership network cannot be explained-in the Swiss case-by the retreat of the state. Two factors that may have played an important role in the Swiss case were the emergence of new types of owners, in particular pension funds, hedge funds, and other institutional investors, and increasing merger and acquisition activity that helped remodel the Swiss ownership network (see Schnyder, 2008).

In the Dutch case, likewise, privatizations were not a major driver of change. Government policies did become increasingly oriented toward deregulation of the economy and toward a shift of state-owned firms and public services to the private sector. Many of the previously state-owned enterprises, such as the railway system, public utilities in the energy sector, postal services, and telecommunications, are now independent, private businesses. The public sector has been reduced by means of privatization or outsourcing of former state functions and public services (public transport, postal services, KLM Airlines, DSM, Central Bureau of Statistics, social security, public health, utilities, universities and schools, etc.). From 1994 to 2006 the equity of the Dutch state account was reduced by more than $€ 100$ billion by large- 
scale sales of its assets. Shares in former state enterprises worth more than $€ 60$ billion were placed on the market, together with additional sales of national real estate to the tune of $€ 40$ billion (De Kam, 2007). It has been pointed out, however, that the Dutch privatization programs "can be interpreted as a 'curtsy to the times' rather than the result of a positive, grand design to revitalise the economy" (Hulsink \& Schenk, 1998, p. 255). Dutch state-owned businesses have always had a relatively autonomous position from direct state involvement, making privatization a relatively easy process, with few consequences for corporate networks as well. ${ }^{3}$

The privatization wave of the 1990s in Germany was less important than in Italy, Spain, and France (2\% of GDP between 1990 and 1999). Yet the increase in the small-world statistics for the German ownership network (+20\%) was larger than in France despite fewer privatizations. The increasing small-world properties of German ownership should be interpreted in light of previous research, which found a fundamental decrease in the density of the ownership network (Beyer, 2002; Höpner \& Krempel, 2004; Windolf, 2002). Rather than analyzing privatizations as we have done, the authors just cited focus on the decline of the traditional crossholdings between the largest firms as the source of the main structural break in Germany. This decline may indeed be a more important factor in the transformation of the German ownership network. The changing preferences of financial companies and increasing opportunity costs linked with the holding of large stakes led during the 1990s to a certain decline in the traditional ownership network among the largest German firms. The Eichel Plan of 2001, which abolished the capital gains tax on the sale of large blocks of shares, was expected to further spur the unraveling of "Germany Inc.," because it explicitly incentivized blockholders to sell their stakes (Höpner \& Krempel, 2004).

However, despite these changes, the decrease in blockholding and the opening of German companies to foreign investors was much more limited than certain observers have predicted (but see Culpepper, 2009; Goyer, 2007; Höpner \& Jackson, 2006; these authors take the view that the changes were extensive and very consequential). Our data, and the analysis given in chapter 7, indeed cast doubt on the thesis of a structural breakdown of ownership ties in Germany, because the number of ties increased between 1993 and 2000. Changes at the level of the interlock network do not seem dramatic either - the density of the network decreased somewhat ( 0.5 to 0.3 - but this effect may be largely due to the fact that the network was much larger in 2000 than in 1993 (see table 5.2). More importantly, the small-world statistics for the German ownership network increased in very important ways, indicating that the coordination infrastructure of German capitalism was still in place.

Privatization did not, therefore, create distinct differences in the structural evolution of European countries, even if it was far more consequential for Latin countries. However, as we suggested, many of the more profound reforms were to occur in 
the subsequent decade, as the policy of noyaux durs in France, for example, broke down or as financial ownership by pension funds and mutual funds grew in Switzerland, Holland, and Germany. Indeed, we again see an important distinction in ownership type, since pension funds are far more important to northern Europe than to the type of social security funds managed by France and other Latin countries. It is more in the identity of owners than in the structural properties of the governance networks that we see differences.

\section{Corporate Governance Reforms}

The previous section showed how privatization represented a major structural break for some countries, leading to a reconfiguration of corporate networks. However, we also noted that in different countries-especially those with a less statist tradition like Germany, the Netherlands, and Switzerland - this factor of privatization played a secondary role in the structural changes observed. Another important factor is the reform of legal corporate governance rules. We would expect that countries providing better shareholder protection would move toward less connected corporate network structures. This observation is more than a correlational claim because shareholder orientation usually goes together with declining legitimacy for interlocks and capital ties, which are seen as a sign of "collusion." The introduction of codes signals that interested parties want to see more active stock markets that erode traditional ownership patterns; however, as we will see, these codes are far from sufficient to effect the structural change that might be expected.

Corporate governance regulation in Europe has often been described as being in a "state of permanent" reform (Noack \& Zetzsche, 2005), spurred by the need to make national capital markets more attractive in the face of lower barriers to capital circulation (Kamar, 2006) but also by the European Union efforts to harmonize corporate law across the members countries (Ferran, 2004). Most of these reforms aimed at strengthening internal corporate governance mechanisms, empowering shareholders, and enhancing disclosure requirements (Enriques \& Volpin, 2007). To assess whether corporate governance reforms had any influence on the restructuring of corporate networks in Europe, we used the shareholder protection index, develop by the Centre for Business Research at the University of Cambridge (see Armour, Deakin, Lele, \& Siems, 2009; Lele \& Siems, 2006; Siems et al., 2009). This index consists of 10 core variables that act as proxies for the level of shareholder protection provided by a given country's regulatory environment. The index takes into account not only formal legal rules, but also - with a certain weighting - case law, corporate governance codes, and stock exchange listing rules.

In table 5.10, we refer to the main legislative initiatives that affected each of the core variables. Figure 5.3 shows how in the period 1995-2005, shareholder protection 


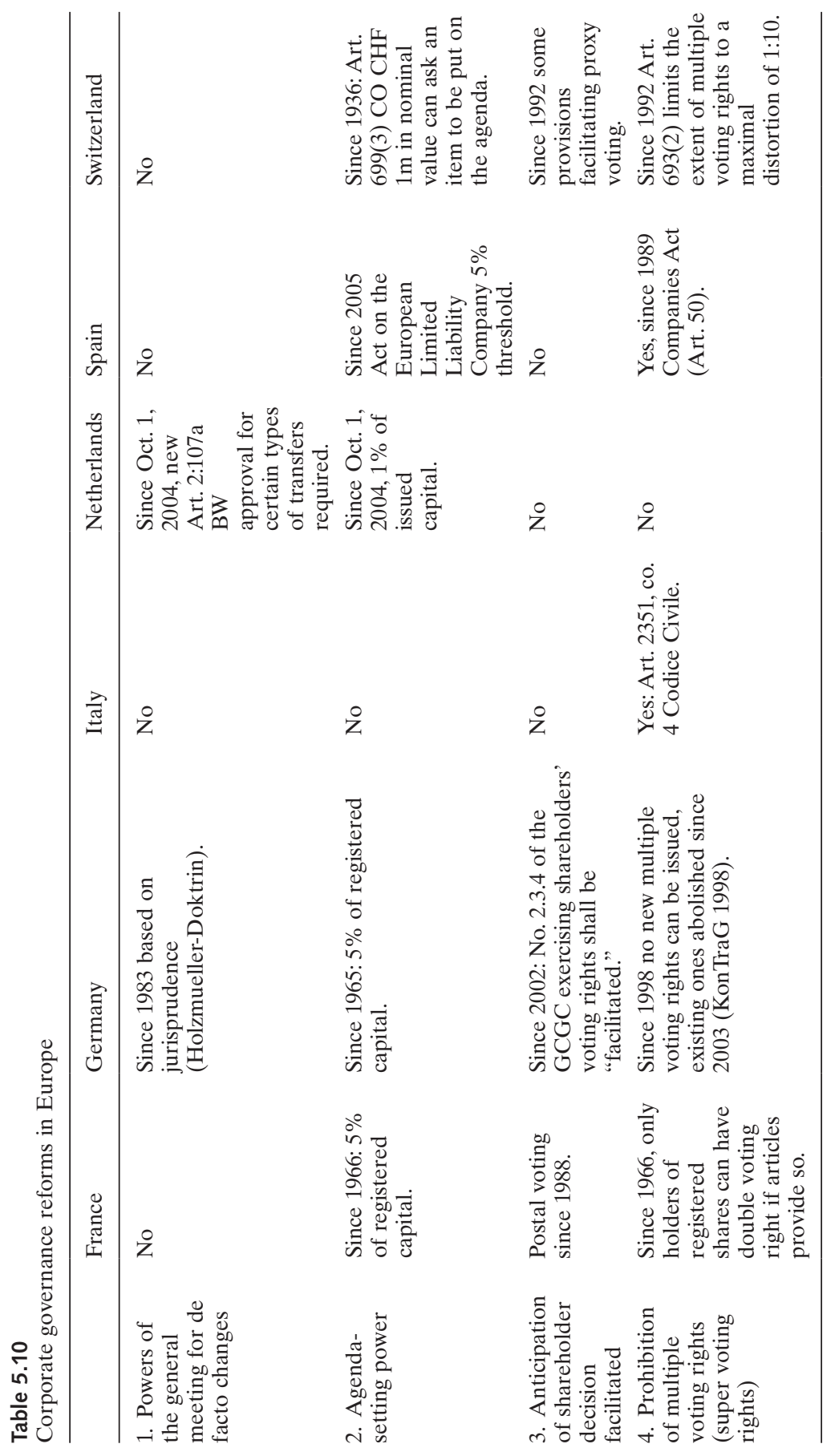




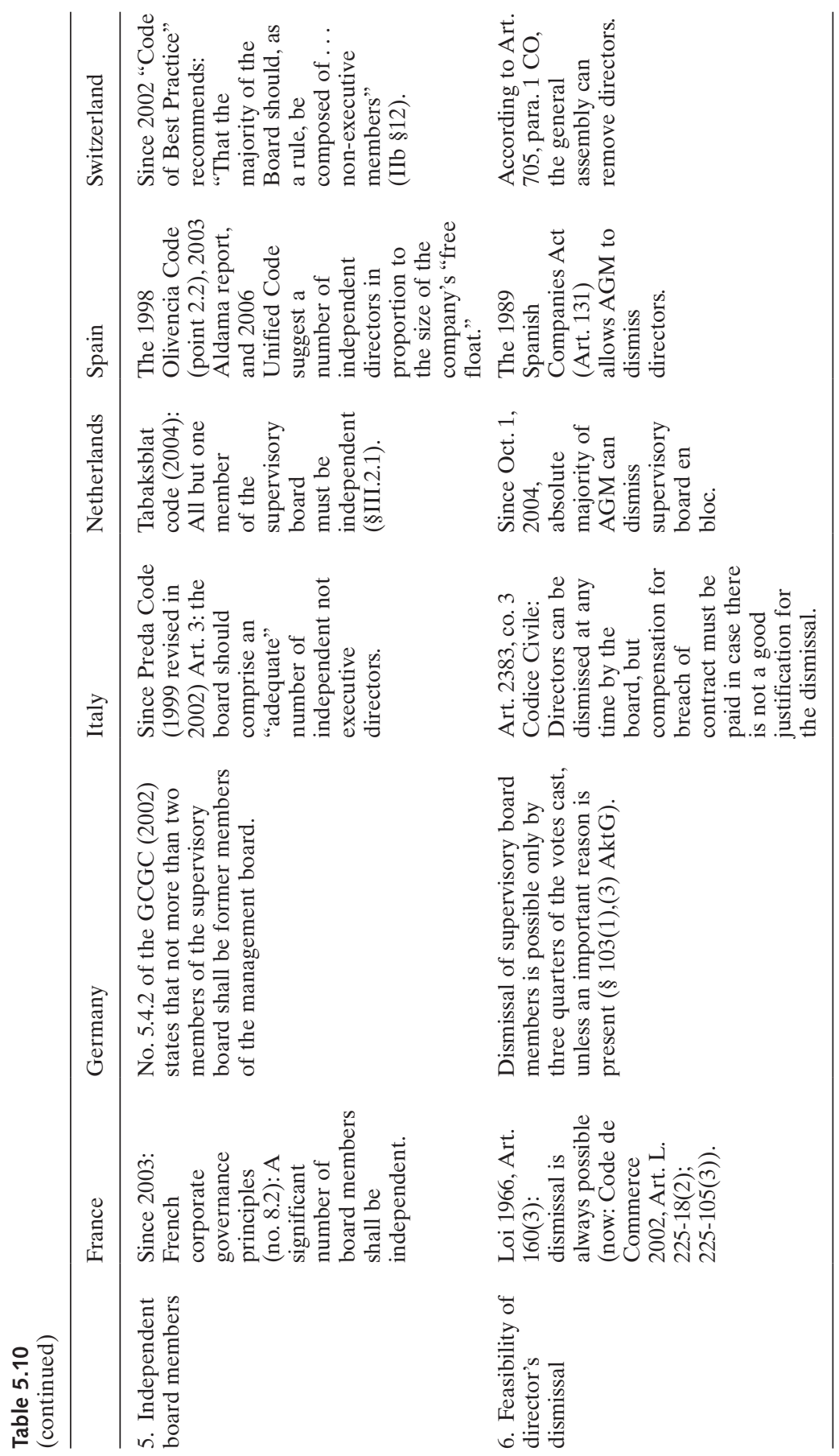




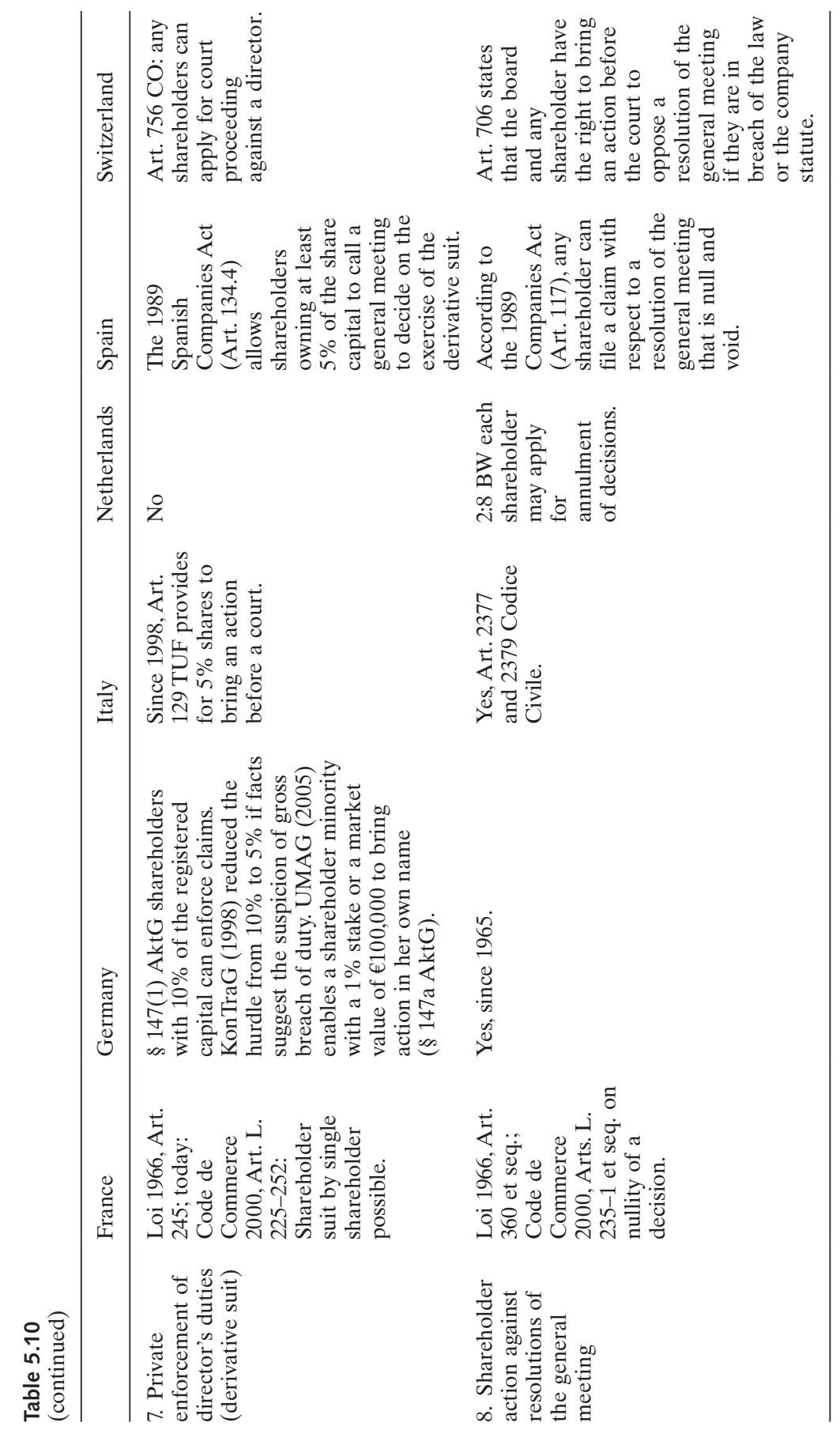




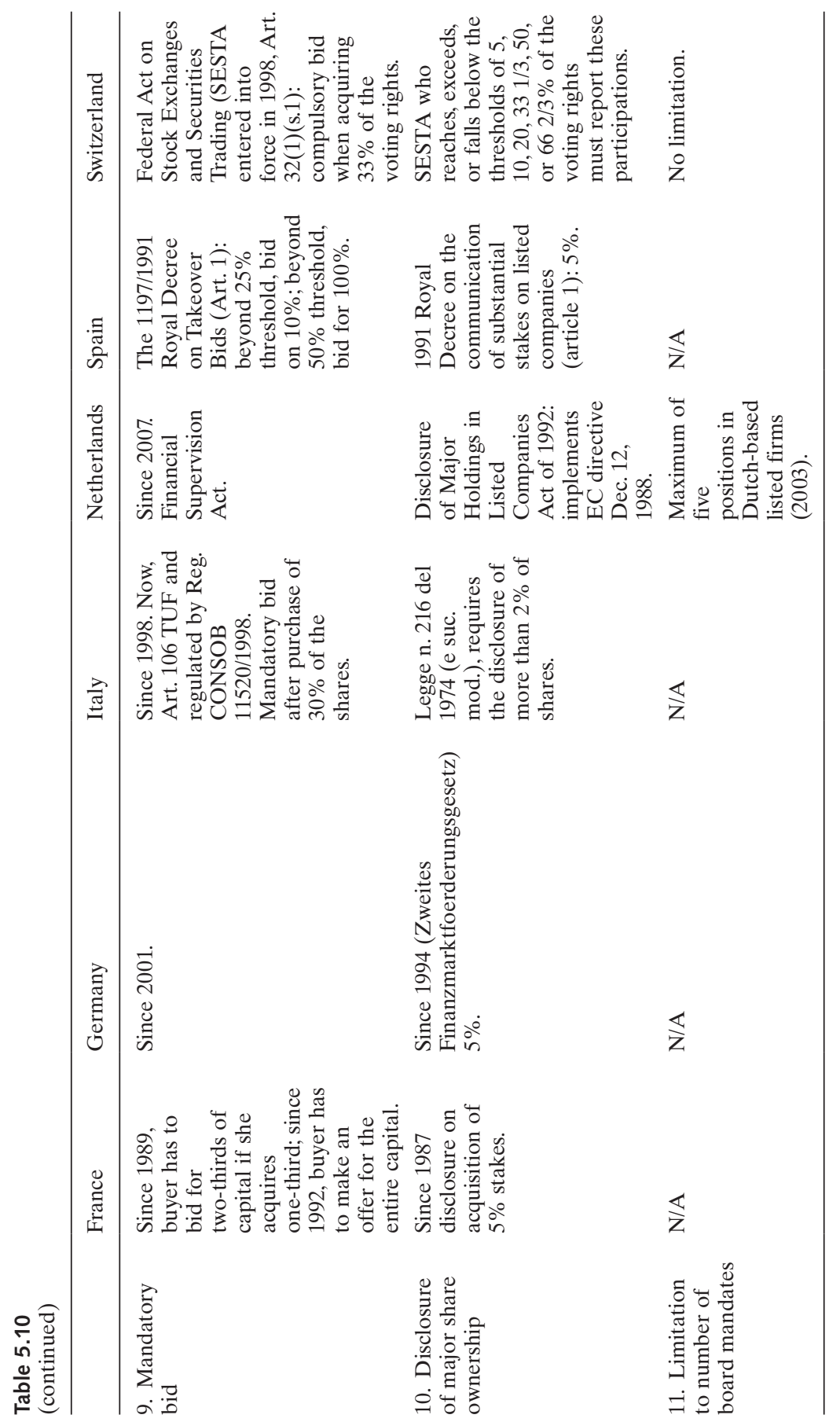




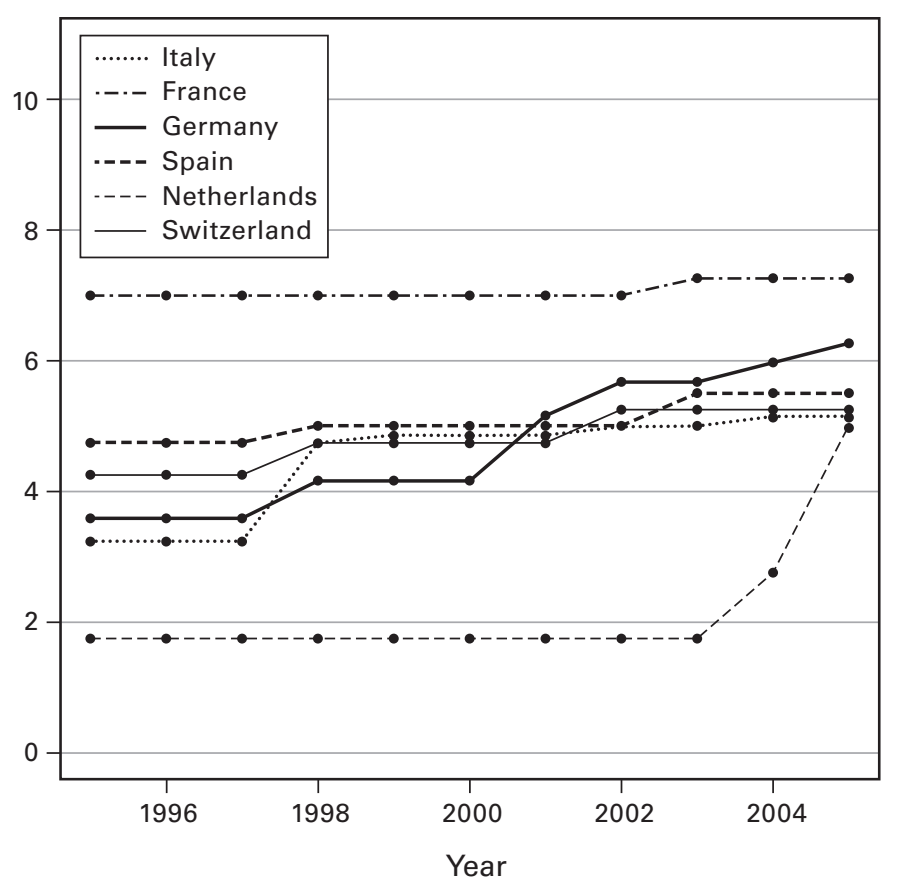

Figure 5.3

Extended Shareholder Protection Index (1995-2005)

increased in all the countries we studied, with the exception of France, where protection was already high by 1995. Germany, Italy, Spain, and Switzerland seemed to be on a similar path toward an improvement of shareholder protection, while the Netherlands only improved shareholder protection more recently.

As mentioned above, better shareholder protection can be expected to go together with less connected corporate networks. Indeed, in the 1990s French, German, and Swiss board interlock networks became less dense, while the Dutch interlock network became denser (table 5.8). This is broadly consistent with the trends in regulatory shareholder protection. Yet in Italy and Spain, board interlock networks became more connected despite important governance reforms. One explanation for this result may be the fact that Italy and Spain introduced regulations requiring the presence of "independent board members" before 2000, while the other countries adopted such regulations only after 2000. When companies replace inside directors with outside directors - who often come from other companies - it seems plausible that links with other companies may increase. A small group of these independent directors may therefore explain the increase in the small-world structures of these networks during the decade we focused on. The increase in board 
interlocks caused by the move toward independent directors may not have been the intended consequence of the introduction of corporate governance codes!

These inconclusive results are not surprising, given that previous literature had already emphasized that legal reform had been insufficient to trigger governance regime change in at least some of the cases we studied. For instance, discussing the failure of Italian policymakers to dismantle the concentrated family shareholding model, a commentator concluded that "government policymakers shot their entire quiver of arrows at the Italian model of capitalism, and all that emerged was an Italian model where concentrated and family ownership remained, while state ownership faded" (Culpepper, 2007, p. 799; see also Pagano \& Trento, 2003). Similarly, despite tax incentives and the prohibition of dual-class-shares, the German system of corporate control appears to resist change to a larger extent than many observers expected (Culpepper, 2009). Indeed, both privatizations and governance reforms only create opportunities that corporate actors might or might not take depending on their agenda and their interdependence with other actors.

In other words, networks - like other "institutions" - are not only constraints, but also indicate opportunities for social actors. Who took advantage of these opportunities? What consequence did their action have on the aggregate structure of the corporate network? In the next section we briefly discuss this question.

\section{Actors and Opportunities}

The previous sections used the small-world concept to assess the changes in six developed economies' intercorporate networks. In this section we attempt to show some limitations of this concept. We argue that different structural breaks may upset existing network relations, but that we can only understand and explain crossnational differences by looking at the actors who take advantage of the opportunities offered by changes in the network structure or the rules producing these structures. This is true for the case of privatizations (who picked up the pieces?) as well as the question of corporate governance reforms (e.g., who are the new independent directors?).

The answer to these questions deserves a study that goes beyond the scope of this chapter. In this section, we provide a brief discussion of this question in relation to privatization, showing that the role of one central actor in corporate networksbanks - varied across countries and that this has had important consequences for the evolution of network structure.

Crucial to any attempt to understand how privatization affected network structures are government policies concerning privatization. In different European countries, governments were anxious to guarantee that privatized companies would remain in the hands of domestic companies and/or individuals. New links among 
domestic companies were thus created mainly for political reasons. Financial institutions were particularly apt to take advantage of the opportunity provided by privatization. A glance at the centrality of banks and insurance companies in the six countries indeed seems to suggest that privatization and the purposeful placement of blocks of shares with "friendly" financial companies constituted a major contributing factor to the networks' persistence at a time when extramarket coordination and links between companies were increasingly discredited.

In many European countries, financial companies were traditionally the linchpin of the company networks (see Stokman et al., 1985). Their declining centrality in national networks has caused major changes in different countries (see Beyer, 2002, for Germany; Davis \& Mizruchi, 1999, for the U.S. case; Schnyder, Lüpold, Mach, \& David, 2005, for Switzerland). Banks' declining centrality has been attributed to corporate finance (less reliance on bank lending) and shifting banking strategies (reorientation toward fee-based and financial market-related activities, less focus on corporate lending) (Davis \& Mizruchi, 1999).

In tables 5.11 and 5.12, we compare the centrality of individual firms in the network of interlocking directorates. We use eigenvector centrality (Bonacich, 1987). Recall the Davis and Mizruchi (1999) finding for the United States regarding the causal link from the growth of capital markets, the declining importance of bankderived financing, and thus the diminution of the number of bankers on boards of directors. Given the changes that European financial systems were experiencing, we would expect financial institutions to have disappeared from the list of the top firms in terms of centrality. This is not what happened initially in most countries, however. In France, BNP-Paribas together with the insurance company AXA remained on the list of the 10 most central firms. This structural persistence can be explained by the above-mentioned government policy of creating "hard cores" of friendly investors due to which "the banks and insurance companies acquired a significant share of industrial capital for the first time. [As a result], the major banks and insurers were financially involved in privatized industrial firms by membership in the hard core of investors as well as on their boards of directors" (Schmidt, 2001, p. 70). These noyaux durs certainly contributed to the increasing small-world property of the French ownership network during the 1990s.

The French state had banked on the hope that even if the "form had changed, the function would persevere," to paraphrase our initial discussion. However, as labor weakened in France, the pivotal positions gained by AXA and other players and their eagerness to continue with their international expansion led to a far more economically liberal orientation in the first decade of the 20th century. The weakening of the French state could not be compensated for by strong worker organizations. What emerged was a growing coalition of managers and shareholder investors (Gourevitch \& Shinn, 2005). 


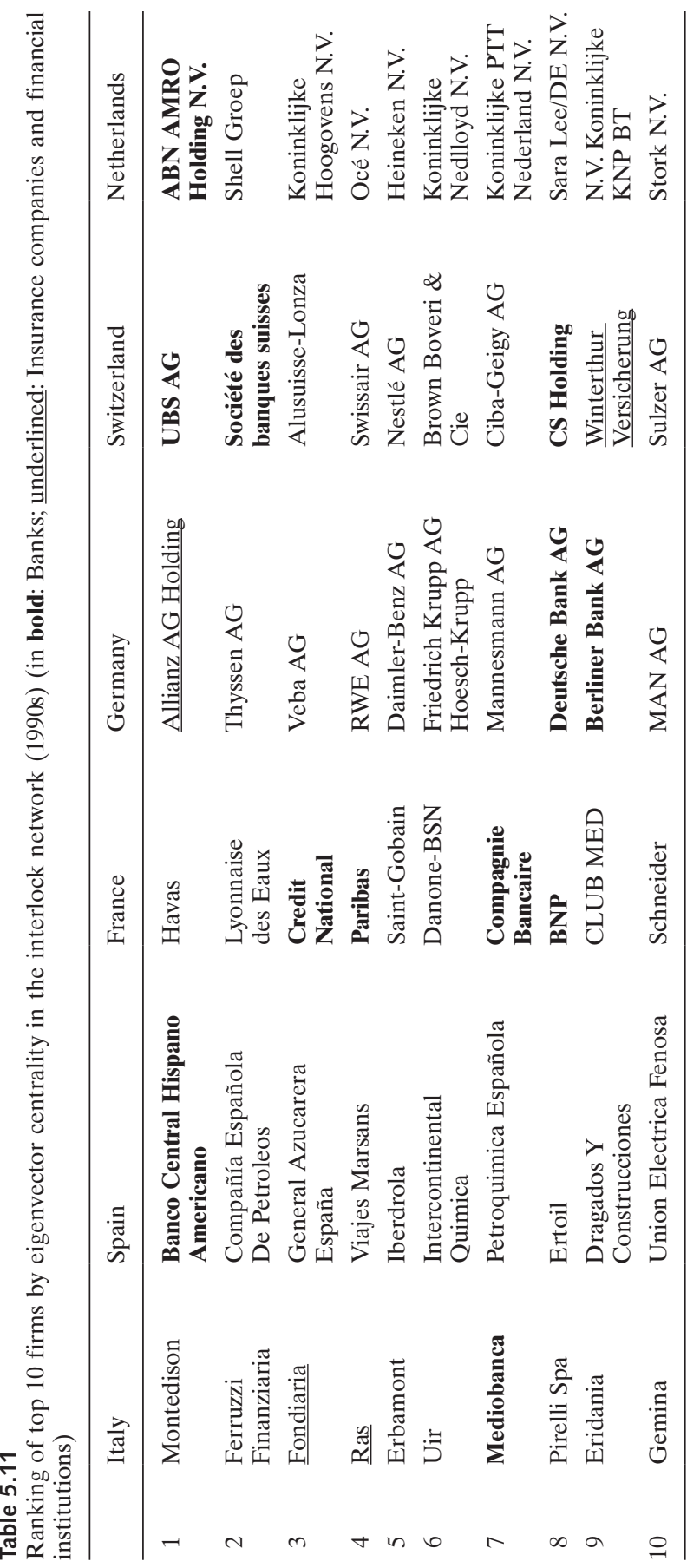




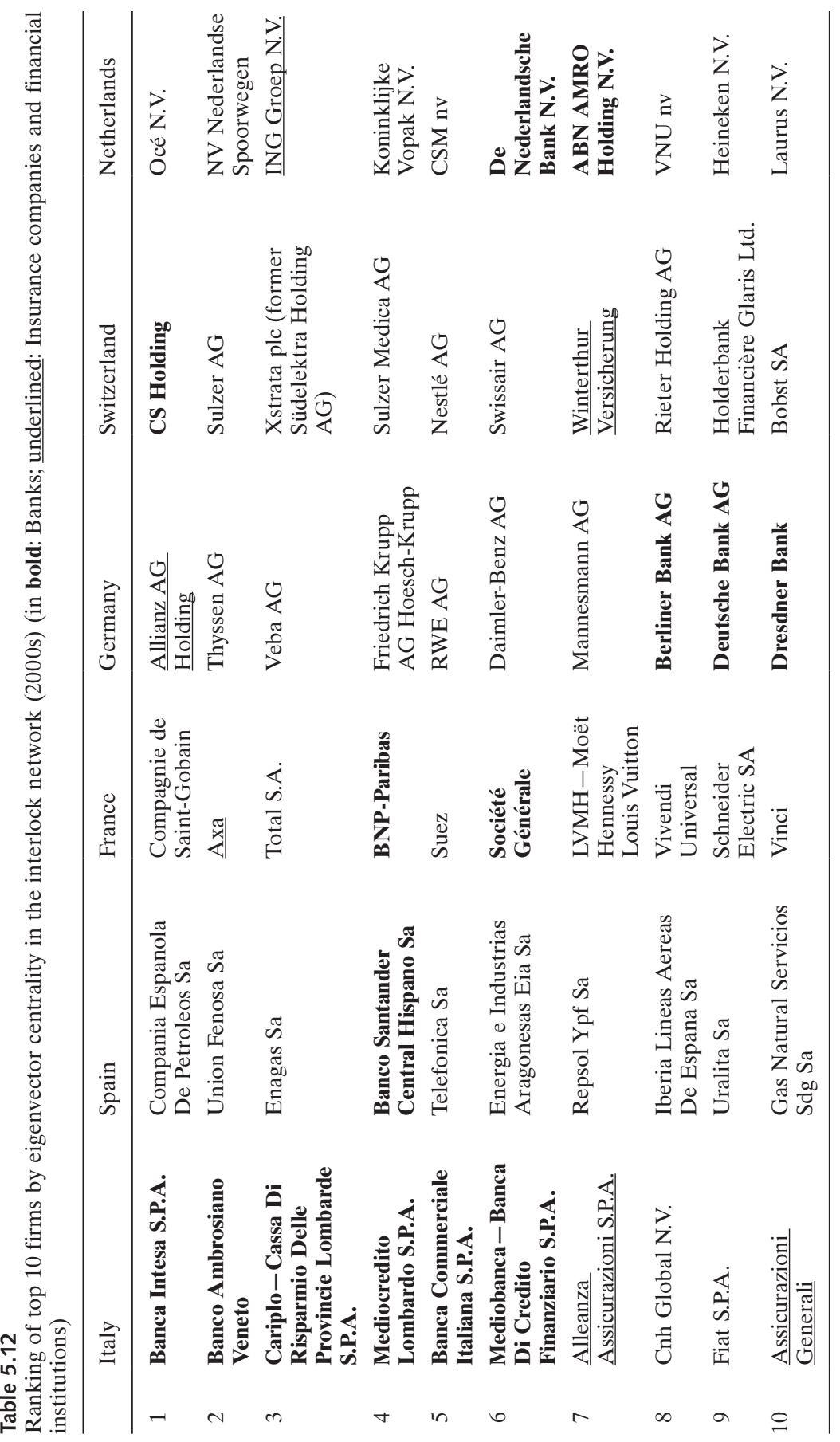


Italian banks became even much more central in the network of interlocking directorates. This too was clearly an effect of the privatizations of the 1990s: the Italian banking system has been almost completely controlled by the state until the privatization wave of the 1990s, then the privatizations allowed the banks to pick up the pieces and become major players. Unlike France, though, the Italian state remained a clever, if not cynical, actor in the subsequent decade, allying business and politics through a popular coalition.

Banks and financial institutions in the northern countries remained dominant, though for Switzerland, they declined in relative importance. For Germany, the top 10 most central companies' ranking for 2000 showed an increase in the positions of banks in the interlock network. Dresdner Bank joined Deutsche Bank and Berliner Bank among the 10 most central companies. Still the story of Germany, as discussed in chapter 7, was not of continuing bank dominance, but rather of the reemergence of the coalition of managers and workers.

In Switzerland, on the other hand, bank centrality had already declined markedly. By 2000, only Credit Suisse and Winterthur Insurance were still among the top 10 companies, while the successor company of UBS and SBS - both among the most central companies in 1990-disappeared from the ranking. The new UBS was to become headed by an American CEO and to represent an interesting balance between the liberal market skills of its acquired First Boston investment bank and the more traditional retail and private wealth bank in the Swiss tradition.

In the Netherlands, finally, banks remained relatively central in the network for two main reasons. First, concentration due to mergers meant that only a few large financial institutions were left during the 1990s, such as ABN-AMRO, ING, and Rabobank. The boards of these remaining financial giants were well-sought venues for the corporate elite to meet. Second, many of the largest banks had already done away with most of their board interlocks before the early 1990s (Heemskerk, 2007).

In some cases, the privatizations had indeed increased the impact of this structural break on the network structure. This was most marked in Italy, where the policy of favoring ownership by Italian banks had led to an increasing centrality of banks and to a more connected network in terms of small-world characteristics. A similar effect was at work in France. But the Swiss case indicates that in the absence of privatizations, the effect of changing bank strategies and their lower propensity to interlock has not been a sufficient shock to disrupt the governance network, as measured by the small-world statistics for both interlocks and ownership.

\section{Conclusions}

The preceding analysis shows that while all countries showed small-world characteristics in 1990 and 2000, the evolution of network structures varied from one 
country to the other. We observe a mild convergence across countries in the sense that the small-world statistics became more similar. However, for certain countries this convergence implies that the network became less small worldly, while it implies for others that they became more so. Moreover, different countries experienced contradictory patterns of evolution in ownership and interlock networks, one becoming more of a small world, the other less so. Only Switzerland and Italy experienced a relative increase in SWI in both networks. In all, though, they remained small worlds.

The small-world analysis allows us to qualify accounts of the demise of coordinated market economies and a rapid convergence on an Anglo-Saxon model of governance. At least at the level of intercorporate network, the infrastructure for coordination seems to still be in place. Yet again, this assessment is based on the "functional" characteristics of the network derived from its structure. We showed that these structural changes - caused by different structural breaks such as privatizations and governance reforms - led to quite different developments in the different countries. We have illustrated this by showing the different roles that banks have played in these countries following privatizations or due to the absence of such privatizations.

Structural breaks such as the globalization of capital, the "financial market revolution," privatizations, and corporate governance reforms generate threats and opportunities. Incumbent elites vie for capturing these opportunities, and there is a need to coordinate their actions. In some cases, existing institutions and elites can coordinate these actions, while in others, new actors manage to acquire this coordination role and become more central in the corporate networks. Financial institutions (banks and insurance companies) are still playing a critical role in Spain, Italy, France, and Germany, but much less critical in the Netherlands and Switzerland.

This mechanism would be consistent with the theoretical insights of different research traditions. In finance, Morck, Wolfenzon, and Yeung (2005) point to the role of entrenchment of elites in guiding the evolution of corporate governance regimes. Gilson (2000, p. 5) stresses the need to go beyond form and focus on the function of different institutional arrangements: "National governance systems turned out to be more adaptive in function, and therefore more persistent in form, than the prophets of convergence expected." Theoretically, this hints at a more fundamental insight from recent research on institutional change in political economy (see notably Hall \& Thelen, 2009; Jackson \& Deeg, 2008; Streeck \& Thelen, 2005 ) - that is, that like other institutions, networks do not evolve automatically as the result of "external shocks" (or structural breaks). Instead actors, whose behavior is partly determined by the institutional setting, also actively contribute to network design. This reflexivity of institutional change constitutes a fundamental insight in sociology that needs to be addressed when studying changes in network structures. It also points to one limitation of the small-world concept: while it adds depth to 
the analysis by considering functional characteristics of the network, it still does not allow us to directly "read" actors' behavior from structural network features.

In economic sociology, Mark Mizruchi (2007) has suggested that in the United States, since the 1980s, a "power vacuum" has emerged at the top of the U.S. business community. If there is a vacuum at the top of the European business community, are new players emerging to play this coordination role? Who are they?

One possible answer is that in a context of higher uncertainty and shifting identities, the only players who can reliably play a coordination role in these systems are the ones whose governance structure keeps them independent. Coordination roles might help political actors (workers, managers, and owners per the framework of Gourevitch and Shinn, 2005) develop governance coalitions that, with the appropriate institutional incentives, lead to entrepreneurial growth. Hence the need for autonomy guaranteeing their ability to deliver political compromise. Traditionally this role had been played by the state, but the evidence touched on in this chapter indicates other actors might enjoy similar, if not higher, levels of autonomy and could play a similar role.

Italian banks, for instance, were shielded until recently from takeover attempts by an overprotective Banca d'Italia. Indeed, despite poor economic performance and a few brave attempts by foreign banks to enter the market (the Spanish BBVA tried to buy Banca Nazionale del Lavoro in 2005, but the central banks eventually managed to fend off the takeover attempt), they remained independent and their mergers were orchestrated in the attempt to build two national champions. Eventually these champions emerged as Unicredito and Intesa-San Paolo. In Spain, regional savings banks, such as La Caixa, whose governance structure shields them from hostile takeovers, emerged as key players in the Spanish economy (holding substantial blocks of shares in national champions Telefónica, Repsol, and Gas Natural). In Germany, the "locust debate" has led to a feeling that new institutional investorshedge funds and private equity firms, for instance-play a major role in the German economy. ${ }^{4}$ However, the empirical evidence suggests that the traditional actors are still dominant despite the opportunity to abandon their traditional position.

Yet, leaving aside the directionality of change, the overall conclusion is that the structural small-world properties were rather robust despite privatization and liberalization in the 1990s. The identity of the nodes often changed, but the structure of sparse connectivity yet short path lengths and high clustering persisted. These European countries remained small worlds. However, the political economy behind this persistence varies remarkably in each of these countries, especially among the Latin countries, where the vacuum created by state retreat in France and Spain led to very different outcomes. In Italy, the eroding state was bolstered by an alliance with business, a situation distinctly anachronistic and ultimately unstable.

When the 2008 financial crisis hit, the battle to occupy these coordinating roles intensified. The uncertainty generated by the financial crisis and its aftermath made 
the political conflicts around them even more apparent. All over Europe the financial sector needed government intervention and underwent a major consolidation. The Spanish regional savings banks, for instance, saddled with bad real estate loans, were forced to accept new regulations reducing their autonomy and likely their ability to play any critical coordinating role. It is too early to assess whether these changes will tip the structure of the corporate networks in different directions, but in line with the main findings of this chapter, we expect that novel actors will emerge to coordinate the definition of novel political coalitions. The interesting question is whether these actors will be national, or has the moment of crisis finally permitted a more decisive role for pan-European institutions and actors? No matter if national or European, it is hard to foresee the persistence of the power of labor, and thus the real battle will be between shareholders and managers, with the issue left open as to the powers and efficacy of the European Union's proper role.

\section{Notes}

The excellent research assistance of Jordi Torrents and the skillful coding of Jordi Colomer were essential for conducting the empirical analysis, and their assistance is gratefully acknowledged. We thank Michel Goyer and Bruce Kogut for generously sharing their data on France and Germany and Bruce Kogut for his guidance and encouragement throughout the project. We also would like to acknowledge generous funding from the Spanish Government Research Grant (Ministerio de Educación y CienciaSEJ2006-11833), the Public-Private Sector Research Center (SP-SP), and the Center for Globalization and Strategy at IESE Business School. Swiss data was collected in connection with a research project on the history of corporate governance in Switzerland funded by the Swiss National Science Foundation (grant no. 1214-068112.02/1) and directed by Prof. Thomas David and Dr. André Mach, University of Lausanne.

1. In relation to the countries we consider in this chapter, see, for instance, the work on Germany (Ziegler, Bender, \& Biehler, 1985; Kogut \& Walker, 2001), France (Swartz, 1985), Spain (Aguilera, 1998), Italy (Chiesi, 1985; Corrado \& Zollo, 2006; Ferri \& Trento, 1997), the Netherlands (Heemskerk \& Schnyder, 2008; Stokman, Wasseur, \& Elsas, 1985), and Switzerland (Nollert, 1998, 2005; Rusterholz, 1985; Schnyder, 2008). Few comparative and/or supranational studies exist. See, however, Stokman, Ziegler, \& Scott, 1985, 1987, 1991a; Windolf, 2002; Carroll, 2002.

2. It should be noted, however, that the important increase in the Swiss ownership network's cohesion is certainly in part due to the changing data sources. Indeed, no legal obligation to disclose major shareholding or to report blockholders existed prior to 1995. The data for 1990 stems, therefore, from a survey carried out by Bank Julius Bär. While including the major listed companies in Switzerland, the data still relies on the voluntary disclosure by issuers themselves, which may lead to very incomplete data. Moreover, certain companies arguably did not know who held their shares, because anonymous bearer shares were widespread and the shareholders had no obligation to disclose their stakes. The 1990 data for Switzerland therefore certainly largely underestimates the number of ownership ties between companies.

3. Indeed an analysis of state ownership in the Netherlands reveals that, during the 1990s, state ownership remained quite stable in our sample of companies, and therefore we should infer that privatizations did not affect the drop in SWI we observe in the Netherlands.

4. The locust debate refers to the appellation of locusts (or Heuschrecken) to private equity investors given by the head of the German Social Democrats, Franz Müntefering. See http://de.wikipedia.org/wiki/ Heuschreckendebatte. 